\title{
二層積層ハニカムコアサンドイッチパネルの 落鍾衝撃特性に及ぼす積層コア高さの比率の影響*
}

\author{
Effect of Core Height Ratio on Drop Weight Impact Properties of \\ Double Layer Honeycomb Core Sandwich Panels \\ Yoshinao KISHIMOTO*1, Toshihisa OHTSUKA, \\ Yukiyoshi KOBAYASHI and Naoyuki ONODERA \\ ${ }^{* 1}$ Department of Mechanical Engineering, Tokyo City University \\ 1-28-1, Tamazutsumi, Setagaya-ku, Tokyo, 158-8557, Japan
}

岸本 喜直 ${ }^{* 1}$, 大塚 年久 $* 1$, 小林 志好 ${ }^{* 1}$, 小野寺 修之 ${ }^{* 2}$

\begin{abstract}
A honeycomb core sandwich panel (hereafter, HSP for brevity) is superior in impact absorption under whole surface compression, because of the buffer effect of core. However impact properties of HSP under local compression such as drop weight impact are affected by the plate as the face sheet in addition to the core layer. This research describes drop weight impact properties of double layer HSP which consists of two core layers and three plates. In order to build up the experimental database for design of double layer HSP, a series of drop weight tests was carried out by using double layer HSPs with the several ratios of the core heights. From obtained results, the follows were summarized: 1) Two or three peaks of the load appeared in the load-displacement curve. The peak loads were larger in sequence of their appearances. 2) In the load - displacement curve until the last peak of the load, there are load increase regions by deep drawing of the plates and load equilibrium regions similar to plateau region under whole surface compression. 3) When the height of the upper layer core was lower, the absorption energy was larger in total. 4) An energy absorption model has been developed and verified for design of double layer HSP.
\end{abstract}

Key Words : Honeycomb, Laminated Construction, Deformation Characteristics, Impact Strength, Absorption Energy, Buckling, Material Testing

\section{1. 緒言}

ハニカムコアサンドイッチパネル (以下, HSP と呼称する) は蜂の巣状のコア材を上下から表面板となる二枚 の平板で挟み，接合した複合構造材料である.HSP は容積の $95 \%$ 以上が空気で構成されているために軽量であり， かつコアの座屈による衝撃緩衝効果に優れている.この特徴を利用して, HSP は自動車などの衝撃緩衙用材料や 航空機の床材，車両の壁材等に広く使用されている ${ }^{(1) \sim(6)}$. しかし，HSP は关の構造上，パネル全体に一樣な荷重 が作用する場合には強いが，局所的な荷重が負荷されると，表面板の作用点近傍はたやすく凹む．特に，局所的な 衝撃荷重は全面圧縮 ${ }^{(7) \sim(13)}$ の場合と異なり，表面板の作用点近傍と炎の直下のコアだけで支えることになるため， HSP の衝撃特性にはコア材だけでなく表面板となる平板の機械的性質が大きく影響することになる ${ }^{(14) \sim(17)}$.

本研究では, 全面圧縮においてエネルギー吸収量がより大きいHSP として , 二層に積層されたコアと三枚の平板 で構成される二層積層 HSP ${ }^{(18) \sim(21)}$ に注目し, 局所的な衝撃荷重を負荷する落鍾衝撃試験によって, 二層積層 HSP

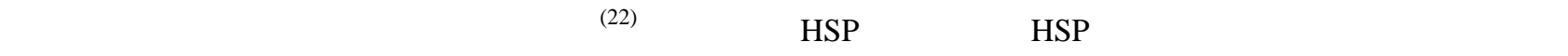
動エネルギー (以下, 落錘エネルギーと呼称する) を変化させて落錘衝撃試験を行った．炎の結果，1) 二層積層 HSP は単層 HSP よりも大きい衝撃荷重に耐え, かつ小さい変形で単層 HSP と同程度のエネルギーを吸収できる

* 原稿受付 2011 年 9 月 25 日

*1 正員, 東京都市大学工学部機械工学科 ( $₹$ 158-8557 東京都世田谷区玉堤 1-28-1)

$* 2$ 東京都市大学大学院工学研究科機械工学専攻 ( $\bar{T}$ 158-8557 東京都世田谷区玉堤 1-28-1)

E-mail: ykishimo@tcu.ac.jp 
こと，2) 荷重一変位線図は落鍾エネルギーに依存しないことが明らかとなった．

しかしながら，前報で検討した二層積層 HSP の落鍾衝撃特性は同一寸法の単層 HSP が吸収可能なエネルギー 量までであり，二層積層 HSP 全体のエネルギ一吸収性能についての検討は十分とはいえない，乥こで本論文では， 設計における基礎的実験データの構筑という観点から, 二層積層 HSP の最も基本的な設計パラメータである積層 コアの高さの比率が二層積層 HSP 全体のエネルギ一吸収性能に与える影響を明らかにすることを目的として，二 層積層 HSP の最下層の平板までき裂が発生するのに十分な運動エネルギーを錘に与え，落錘衝撃試験を行った 得られた試験結果から，二層積層 HSP の落錘衝撃特性として，錘に作用する荷重一変位線图ならびにエネルギー 吸収量について考察した .さらに, 基礎的実験データをもとにした設計指針として, 二層積層 HSP のエネルギー 吸収モデルを作成し，光の有効性について検証した .

\section{2. 実 験 方 法}

\section{$2 \cdot 1$ 試験片}

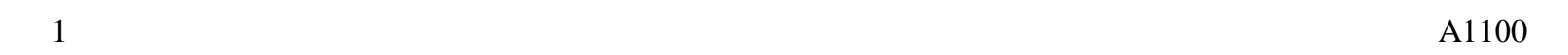
用いた . 平板の厚さを $t_{p}=0.3 \mathrm{~mm}$ とした . コアは寺岡製作所製両面接着テープNo. $778 \mathrm{~K}$ を用いて展張式によっ て製作し，図 1 に示すようにコアのセルサイズを $S=17.3 \mathrm{~mm}$ ，セル壁の厚さを $t_{c}=0.04 \mathrm{~mm}$ とした .

試験片の形状は図 2 に示すようにコアを二層に積層したものであり， Newport 社製接着シート NB-102 を用い

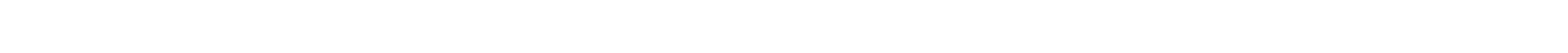
板すなわち表面板について，衝突面となる平板を上板，もう一方の平板を下板と呼称する．また，コア間に挟ん だ平板を中板，衝突面に近いコアを上層コア，残りのコアを下層コアと光れ光れ呼称する．

試験片の外形寸法は長さ $l=200 \mathrm{~mm}$ ，幅 $b=200 \mathrm{~mm}$ の正方形とした . 本実験では表 2 に示すように，積層コ アの高さの比率の影響を調べるためにコアの総高さ $h\left(=\right.$ 上層コアの高さ $h_{1}+$ 下層コアの高さ $\left.h_{2}\right)$ を $30 \mathrm{~mm}$ 一定 として, 上層コアと下層コアの高さを変化させた 5 種類の試験片(1)〜 (5)を用意した . 試験片(1)から(5)になるほど， 上層コアの高さ $h_{1}$ は高くなる．本研究では，これら 5 種類の試験片について，光れ光れ 5 本ずつ落錘衝撃試験を 行った.

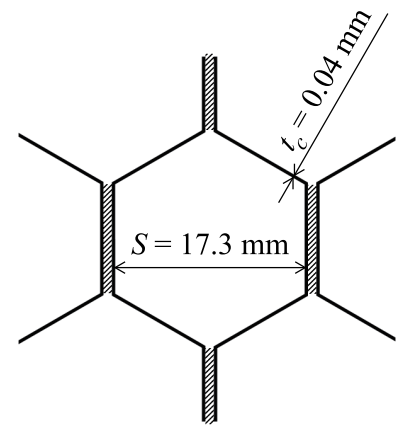

Fig. 1 The geometry of the honeycomb core

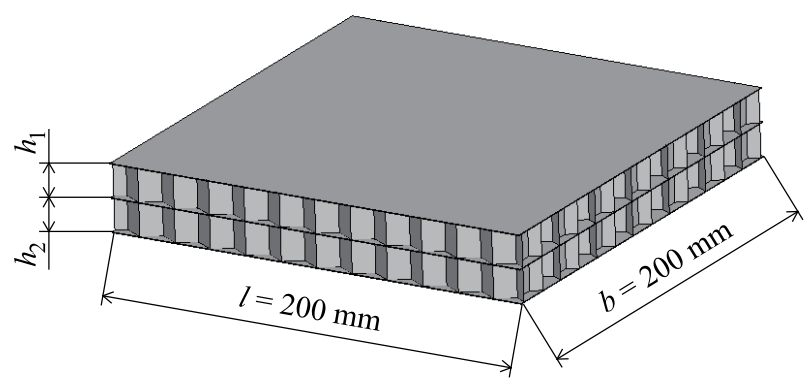

Fig. 2 The shape of the specimen

Table 1 The constituent materials of the specimens

\begin{tabular}{|c|c|c|}
\hline \multirow{3}{*}{ Plate } & Material & A1100 \\
\hline & Thickness: $t_{p}[\mathrm{~mm}]$ & 0.3 \\
\hline & Young's modulus: $E$ [GPa] & 70 \\
\hline \multirow{3}{*}{ Core } & Material & A1100 \\
\hline & Thickness of cell wall: $t_{c}[\mathrm{~mm}]$ & 0.04 \\
\hline & Cell size: $S[\mathrm{~mm}]$ & 17.3 \\
\hline Adhesive sheet & \multicolumn{2}{|c|}{ NB -102 , Made by Newport } \\
\hline Double sided adhesive tape & \multicolumn{2}{|c|}{ No. $778 \mathrm{~K}$, Made by Teraoka Seisakusho } \\
\hline
\end{tabular}


Table 2 The core heights of the specimens

\begin{tabular}{c|c|c|c|c|c}
\hline \hline Specimen & (1) & (2) & (3) & (4) & (5) \\
\hline Height of upper layer core: $h_{1}[\mathrm{~mm}]$ & 5 & 10 & 15 & 20 & 25 \\
\hline Height of lower layer core: $h_{2}[\mathrm{~mm}]$ & 25 & 20 & 15 & 10 & 5 \\
\hline Core height Ratio: $\quad h_{1}: h_{2}$ & $1: 5$ & $1: 2$ & $1: 1$ & $2: 1$ & $5: 1$ \\
\hline
\end{tabular}

\section{$2 \cdot 2$ 落鍾衝撃試験方法}

\subsection{1 落鍾試験機}

図 3 に落鍾試験機の概略図，表 3 に各測定器の詳細を光れ光れ示す、落鍾衝撃試験は治具により周辺固定した 試験片の中央に錘が衝突するように，初速を加えず自由落下させることにより行った．本試験で使用した錘の材 質には S45C を用い, 产の質量を $m=13.1 \mathrm{~kg}$ とした .錘の先端部分の形状は JIS K 7211 (硬質プラスチックの落 鍾衝撃試験方法通則）を参照し，半径 $R=30 \mathrm{~mm}$ の半球状とした . また，図 4 に治具による試験片固定方法の概 略图を示す.試験片の周囲を治具とボルトで固定し，試験部を $140 \mathrm{~mm} \times 140 \mathrm{~mm}$ とした .

実験に際しては，図 3 に示したように鍾に加速度センサを取り付け，試験中に錘に生じる減速方向の加速度 , す なわち減速度 $D$ を動ひずみ測定器によって $\Delta t=50 \mu \mathrm{s}$ ごとに測定した . また，試験機に取り付けた光電センサを 用いて，錘の二点間 (間隔 $L=50 \mathrm{~mm}$ ) の通過時間 $t^{\prime}$ を測定した . ここで, 試験開始前の錘の先端から光電セン サの中央までの距離を $H=500 \mathrm{~mm}$ ，光電センサの中央から試験片の上板までの距離を $H^{\prime}=54 \mathrm{~mm}$ とし，試験開 始前の錘の先端から試験片の上板までの距離である落錘高さを $H+H^{\prime}=554 \mathrm{~mm}$ とした .
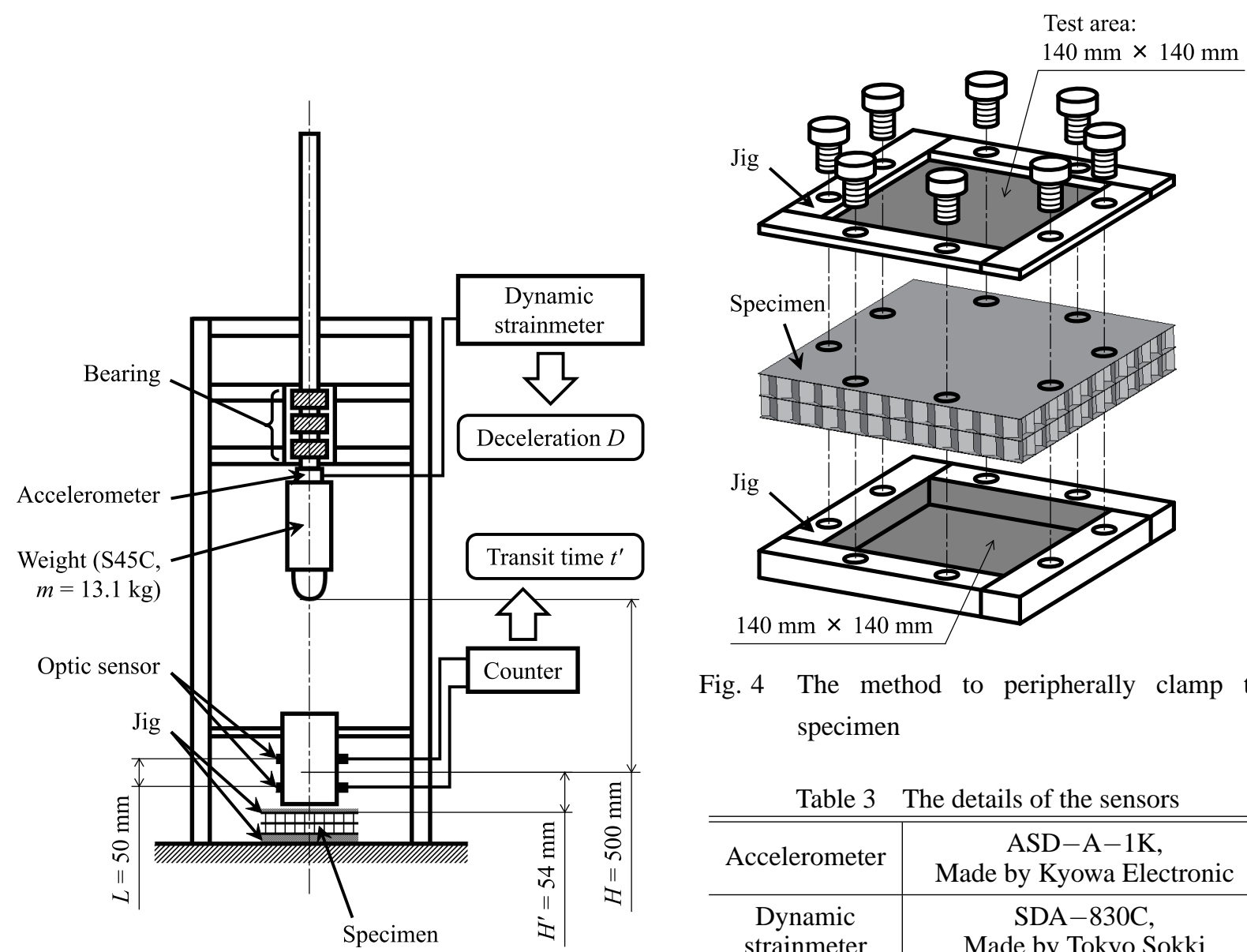

Fig. 4 The method to peripherally clamp the specimen

Table 3 The details of the sensors

\begin{tabular}{c|c}
\hline \hline Accelerometer & $\begin{array}{c}\text { ASD-A-1K, } \\
\text { Made by Kyowa Electronic }\end{array}$ \\
\hline $\begin{array}{c}\text { Dynamic } \\
\text { strainmeter }\end{array}$ & $\begin{array}{c}\text { SDA-830C, } \\
\text { Made by Tokyo Sokki }\end{array}$ \\
\hline Optic sensor & $\begin{array}{c}\text { FS-M1H, } \\
\text { Made by Keyence }\end{array}$ \\
\hline Counter & $\begin{array}{c}\text { SC-7201, } \\
\text { Made by Iwatsu }\end{array}$ \\
\hline
\end{tabular}


2.2.2 衝突直前速度および落鍾エネルギーの算出方法

錘の衝突直前速度 $v_{0}$ は, 落錘試験中の錘の加速度 $a$ が鍾と鍾を支えるベアリングとの摩擦の影響などによって 重力加速度 $g$ よりも小さくなることを考慮し, 鍾の光電センサ間の通過時間 $t^{\prime}$ を用いて以下のようにして求めた 落鍾高さが $H+H^{\prime}=554 \mathrm{~mm}$ と比較的短いことから, 落錘試験中の鍾の加速度 $a$ を落錘開始直後から衝突直前に わたって一定であるとすると，試験機に取り付けた二つの光電センサにおける錘の通過時刻 $t_{1}^{\prime}, t_{2}^{\prime}$ は

$$
\begin{aligned}
& \frac{a t_{1}^{\prime 2}}{2}=H-\frac{L}{2} \rightarrow t_{1}^{\prime}=\sqrt{\frac{2 H-L}{a}} \\
& \frac{a t_{2}^{\prime 2}}{2}=H+\frac{L}{2} \rightarrow t_{2}^{\prime}=\sqrt{\frac{2 H+L}{a}}
\end{aligned}
$$

となるから , 錘の光電センサ間の通過時間 $t^{\prime}$ は

$$
t^{\prime}=t_{2}^{\prime}-t_{1}^{\prime}=\frac{\sqrt{2 H+L}-\sqrt{2 H-L}}{\sqrt{a}}
$$

となる．よって，落錘試験中の錘の加速度 $a$ は

$$
a=\frac{4 H}{t^{\prime 2}}\left[1-\sqrt{1-\left(\frac{L}{2 H}\right)^{2}}\right] \approx \frac{4 H}{t^{\prime 2}} \cdot \frac{1}{2}\left(\frac{L}{2 H}\right)^{2}=\frac{1}{2 H}\left(\frac{L}{t^{\prime}}\right)^{2}
$$

となる．ここで，

$$
(L / 2 H)^{2}=2.5 \times 10^{-3} \ll 1 \quad(\because L=50 \mathrm{~mm}, H=500 \mathrm{~mm} \quad \text { as shown in figure } 3)
$$

であることを利用した .したがって , 錘の衝突直前速度 $v_{0}$ を錘の光電センサ間の通過時間 $t^{\prime}$ から算出するための 計算式として

$$
v_{0}=\sqrt{2 a\left(H+H^{\prime}\right)}=\frac{L}{t^{\prime}} \sqrt{1+\frac{H^{\prime}}{H}}
$$

が得られる．また，落鍾エネルギー $U_{0}$ は

$$
U_{0}=\frac{1}{2} m v_{0}^{2}
$$

より算出できる．

2.2.3 荷重, 変位およびエネルギー吸収量の算出方法

鍾が試験片に衝突してから $t$ 秒後における鍾および試験片に作用する荷重 $P(t)$ ，ならびに錘の变位 $\delta(t)$ は錘の

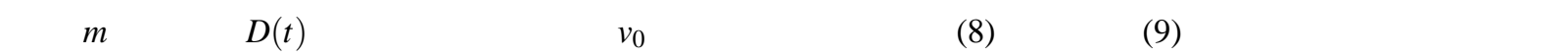

$$
\begin{gathered}
P(t)=m D(t) \\
\delta(t)=\int\left(v_{0}-\int D(t) d t\right) d t
\end{gathered}
$$

また，試験片のエネルギー吸収量 $E$ は鍾に作用した仕事量に相当すると考えられ，次式より求められる．

$$
E=\int P d \delta
$$

なお，本実験によって得られる減速度 $D$ のデータはサンプリング間隔が $\Delta t$ の離散值であるため，式 (9) および 式 (10)における積分は数値積分を用いて計算する.

\section{3. 実験結果および考察}

$3 \cdot 1$ 衝突直前速度および落鍾エネルギー

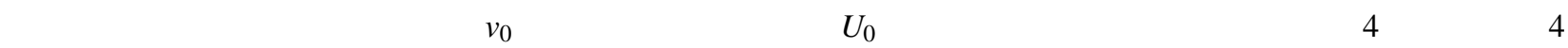
より，すべての試験片に対して衝突直前速度 $v_{0}$ を約 $3.2 \mathrm{~m} / \mathrm{s}$ (落錘エネルギー $U_{0}$ は約 $66 \mathrm{~J}$ ) 一定として落錘衝撃 試験が実施されたことを確認した . 
Table 4 The impact velocity and the impact energy

\begin{tabular}{c|cc|cc}
\hline \hline Specimen & \multicolumn{2}{|c|}{ Impact velocity $v_{0}[\mathrm{~m} / \mathrm{s}]$} & \multicolumn{2}{|c}{ Impact energy $U_{0}[\mathrm{~J}]$} \\
\hline (1) & 3.18 & $\left(9.30 \times 10^{-3}\right)$ & 66.2 & $(0.39)$ \\
\hline$(2)$ & 3.17 & $\left(4.52 \times 10^{-2}\right)$ & 65.7 & $(1.86)$ \\
\hline$(3)$ & 3.17 & $\left(4.39 \times 10^{-2}\right)$ & $65.7 \quad(1.80)$ \\
\hline$(4)$ & 3.16 & $\left(4.34 \times 10^{-2}\right)$ & $65.6 \quad(1.78)$ \\
\hline (5) & 3.18 & $\left(1.11 \times 10^{-2}\right)$ & $66.3 \quad(0.46)$ \\
\hline
\end{tabular}

Indicated value: Average (Standard deviation)

\section{$3 \cdot 2$ 荷重一変位線図}

図 4 に , 各試験片から得られた荷重一変位線図の一例を示す . 参考文献 (22) で既に報告しているように , 荷重一 変位線図は落錘エネルギーに依存しないことから，落錘エネルギーが本実験で与えた值とは異なる場合でも，同 樣の傾向を有する荷重一変位線図が得られると考えられる.

図 4 より,すへての試験片において荷重 $P$ は錘が上板に接触した直後 $(\delta=0 \mathrm{~mm})$ から変位 $\delta$ に対して直線的 に上昇し，ピークに到達した。荷重 $P$ のピークは試験片(2)〜(4)からは三度 $\left(p_{1}\left(P_{1}, \delta_{1}\right), p_{2}\left(P_{2}, \delta_{2}\right), p_{3}\left(P_{3}, \delta_{3}\right)\right)$, 試 験片(1)，(5)から二度確認され，これらのピークは最後のピークで最大となることが分かる . 本研究では, 原点 から荷重 $P$ の最後のピークまでのエネルギー吸収量を試験片か吸収できるエネルギーの限界量 $E_{S}$ (以下, エネル ギー吸収限界量と呼称する）とし，この区間を本研究の研究対象とする .さらに , 各ピーク間 (原点〜 $p_{1}, p_{1} \sim p_{2}$,

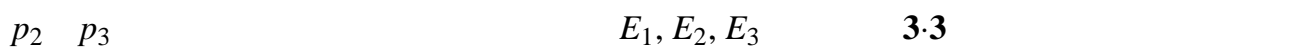

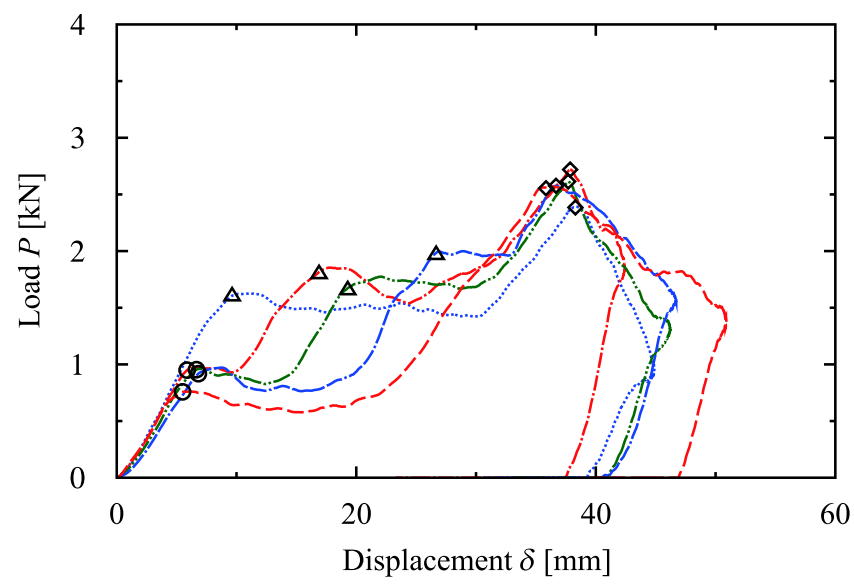

$$
\begin{aligned}
& \cdots \cdots \cdots \cdots . . . \text { (1) } h_{1}=5 \mathrm{~mm}, h_{2}=25 \mathrm{~mm} \\
&---.- \text { (2) } h_{1}=10 \mathrm{~mm}, h_{2}=20 \mathrm{~mm} \\
&-\cdots-. . \text { (3) } h_{1}=15 \mathrm{~mm}, h_{2}=15 \mathrm{~mm} \\
&---- \text { (4) } h_{1}=20 \mathrm{~mm}, h_{2}=10 \mathrm{~mm} \\
&--- \text { (5) } h_{1}=25 \mathrm{~mm}, h_{2}=5 \mathrm{~mm} \\
& \circ p_{1}\left(P_{1}, \delta_{1}\right) \\
& \Delta p_{2}\left(P_{2}, \delta_{2}\right) \\
& \diamond p_{3}\left(P_{3}, \delta_{3}\right)
\end{aligned}
$$

Fig. 4 The example of the load—displacement curve

最後のピーク $p_{3}$ 以外のピーク $p_{1}, p_{2}$ の後, $\mathrm{HSP}$ の全面圧縮時にみられる荷重変動の小さいプラト一領域と同樣 の傾向を示す区間か現れ，兴の後の荷重 $P$ の再上昇は錘が中板あるいは下板の位置 $\left(\delta \simeq h_{1}\right.$ あるいは $\delta \simeq h=30$ $\mathrm{mm})$ に近づいたときであった . 以下, 荷重 $P$ が変位 $\delta$ に対して直線的に上昇する区間を荷重上昇領域 , プラトー 領域と同樣の傾向を示す区間を荷重平衡領域と呼称する . また，ピーク $p_{1}, p_{2}, p_{3}$ 到達直前の荷重上昇領域を光れ

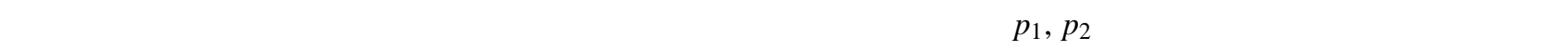
れ一次荷重平衡領域，二次荷重平衡領域と呼称する.なお，すべての試験片において，荷重 $P$ の最後のピーク $p_{3}$ を経た後, 変位 $\delta$ が最大值をむかえ, 光の後弾性回復した . 原点から变位 $\delta$ が最大值に到達した点までのエネル ギー吸収量と落鍾エネルギー $U_{0}$ がほぼ一致したことから，落鍾エネルギーのほとんどか試験片の変形に費やされ たことを確認した .

図 5 に, 試験後の試験片に形成された凹みの写真を示す . 図 5 は図 4 に示した実験結果のうち, 試験片(2)のも のである.図 5 より, すべての平板 (上板, 中板, 下板) の凹みは錘先端の形状に押しつぶさされていることが分 かる . 上板に形成された凹みの中心と上板の試験前の位置との距離は, 図 4 における弾性回復後, 荷重 $P$ が 0 に なったときの変位 $\delta$ と一致した . また, 写真をみて分かるように, すべての平板に形成された凹みの中心近傍に 


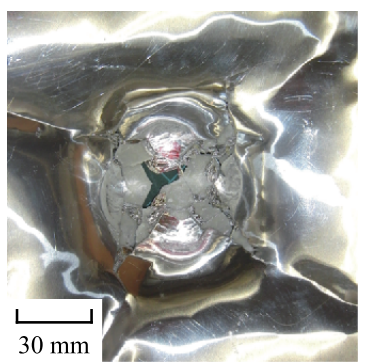

Top view

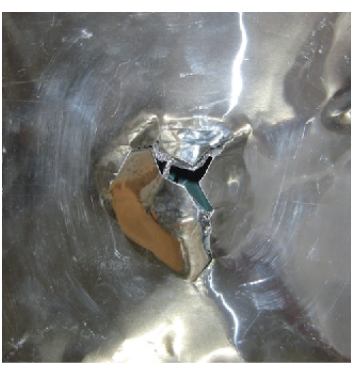

Bottom view

Fig. 5 The feature of the specimen after the test; Specimen (2) $\left(h_{1}=10 \mathrm{~mm}, h_{2}=20 \mathrm{~mm}\right)$

はセル壁に沿って進展したき裂か観察された .これらのき裂は鍾接触部と非接触部の境界から発生しており，開口 していることから，しぼり加工による引張応力の負荷により生じたと考えられる．

以上より, 荷重一変位線図と試験片の変形との関係について, 次のようにまとめられる. 荷重 $P$ のピーク $p_{1}, p_{2}$, $p_{3}$ は HSP を構成する三枚の平板に，上板から下板にかけて順番にき裂が発生することによって現れ，弚れ光れの ピークか現れる前の荷重上昇領域はき裂が発生する前の平板に対する錘の押込みによる凹みの形成によって現れ たと考えられる. 荷重平衡領域はコアの圧潰に加え, 錘による平板のさらなる押込み変形と発生したき裂の進展 によって現れたと考えられ，これは全面圧縮の場合にみられるプラトー領域と異なる ${ }^{(7) \sim(9)(19)(20) . ~}$

また，前述したように図 4 において，一次および二次荷重平衡領域を経た後に荷重 $P$ が再上昇するときの変位 $\delta$ と中板および下板の位置が同程度であったことから，1) $\delta \simeq h_{1}$ までは中板以下 (中板 , 下層コア，下板）の変 形は小さかったこと，2) $\delta \simeq h=30 \mathrm{~mm}$ までは下板の変形は小さかったこと，3) 中板あるいは下板の変形は产の 上に接着された上層コアあるいは下層コアが十分に緻密化してから生じたことが考えられる．

さらに, 試験片(1), (5)から確認された荷重 $P$ のピークが二度であった理由は以下のように考えられる.試験片(2) 〜 (5)の荷重 $P$ の度目のピークはすべて, 变位 $\delta$ が約 $7 \mathrm{~mm}\left(<h_{1}\right)$ のときに発生している . 一方, 試験片(1)の荷 重 $P$ の一度目のピークは変位 $\delta$ が約 $10 \mathrm{~mm}\left(>h_{1}\right)$ のときに発生していることから, 試験片(1)では, 上板にき裂が 発生する前に錘が中板に到達し, 試験片(1)荷重 $P$ の一度目のピークは中板にき裂が発生することで現れたと考 えられる . すなわち，試験片(1)の二度のピークは光れ光れ $p_{2}, p_{3}$ に相当すると考えられる . 同樣にして, 試験片 (5)の二度のピークは光れ光れ $p_{1}, p_{3}$ に相当すると考えられる．

以下では, 本実験によって得られた荷重一変位線図について, 荷重上昇領域, 荷重のピーク, 荷重平衡領域の順 に考察し，次節にて各試験片のエネルギー吸収量について比較と考察を行う．

\subsection{1 荷重上昇領域}

荷重 $P$ か荷重上昇領域で変位 $\delta$ に対して直線的に上昇した理由は以下のように考えられる . 参考文献 (17) で報 告したように, 先端が本落鍾衝撃試験の鍾と同じ半径 $R=30 \mathrm{~mm}$ の半球状の圧子を用いて局部圧縮疲労試験を行っ た場合，破壤起点となるき裂発生位置にかかる荷重は最高深しぼり荷重から計算できることが分かっている．ま た, 試験開始直後の変位 (圧子押込み量) $\delta$ とき裂発生位置との関係を球の幾何学的関係から説明できたので, 最 高深しぼり荷重と試験開始直後の变位の間には次式の関係が成り立つ.

$$
P \propto \sqrt{2 R \delta-\delta^{2}}
$$

この関係は疲労試験結果から導かれたものであるが, カのつりあいと試験開始後の変位は本落錘衝撃試験でも 同樣の扱いとなるので, 今回得られた結果にも当てはめられる . 式(11)において，特に非線形性を示す $\delta=0$ 近 傍の範囲は, 本落鍾衝撃試験では鍾が各平板に接触する前後であり, 弚の力学的挙動は不安定である．また，荷 重一変位線図が直線性を示した变位範囲は錘先端の半径と比べて小さいことから, 式 (11) は直線近似できると判 断される. 谷の結果，各荷重上昇領域で荷重一変位線図の傾きはみかけ上直線的であったと考えられる.

以下, 荷重上昇領域における荷重一変位線図の傾きを変形抵抗と呼称し, 一次 , 二次 , 三次荷重上昇領域にお

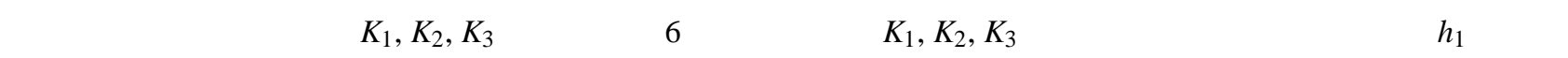
て乥れ光れ示す . 図 6 より，変形抵抗 $K_{1}, K_{2}, K_{3}$ と上層コアの高さ $h_{1}$ の相関はみられず， これらの平均值はすべ 


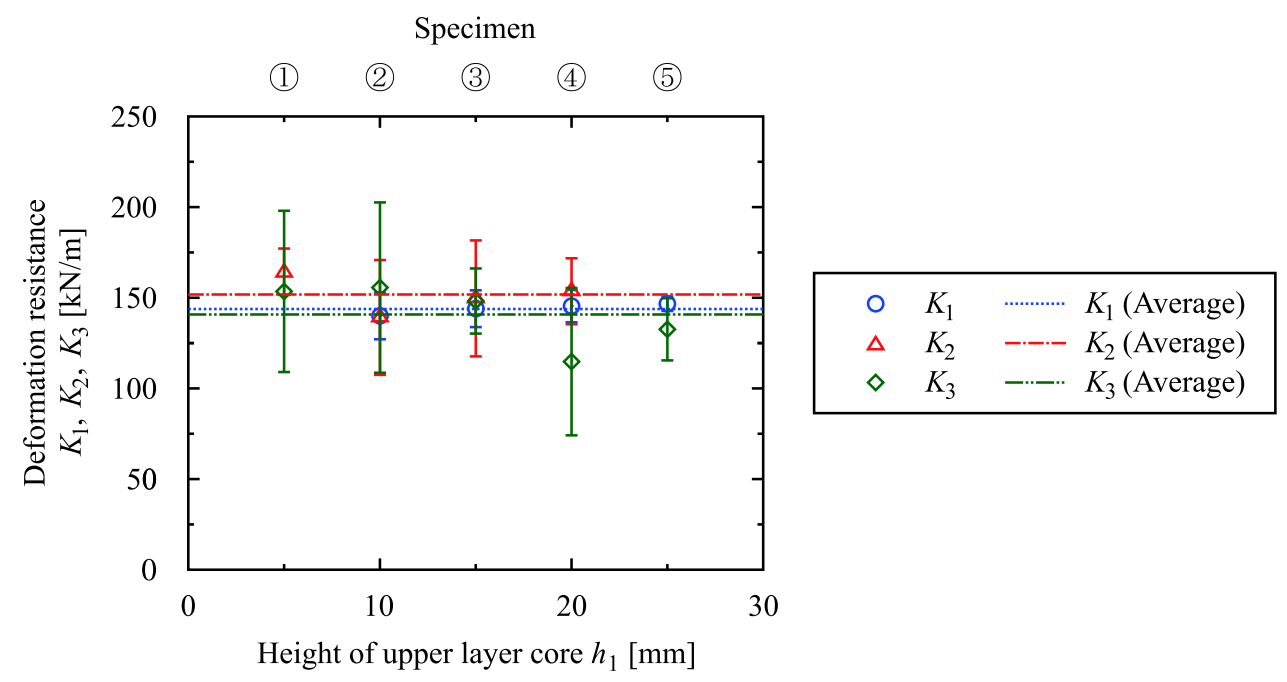

Fig. 6 The deformation resistances

てほぼ等しい值（約 $145 \mathrm{kN} / \mathrm{m}$ ) をとることが分かる. 変形抵抗に及ぼす各層のコア高さの影響が確認できなかっ たことから，コアによる押込みの抑制効果は小さく，各平板による押込みの抑制効果が大きく影響していたこと になる．このようになった理由として，今回の実験で用いたコアのセル壁の厚さが $t_{c}=0.04 \mathrm{~mm}$ と薄かったこと， およびコアが十分に緻密化する前に荷重 $P$ のピークが現れたことが考えられる . また , 変形抵抗は大きいもので 約 $200 \mathrm{kN} / \mathrm{m}$ ，小さいもので約 $70 \mathrm{kN} / \mathrm{m}$ とばらついた . 変形抵抗のばらつきの原因として以下のことが考えられる 例えば，円板の平面曲げにおける最大たわみは支持点間距離に依存する . 凹みの外周部をこの円板の外周部支持 点とみなせば，凹み外周部の大きさあるいは形状の違いが変形抵抗の大きさに影響を及ぼしたと考えられる .

\subsection{2 荷重のピーク}

図 7 および図 8 に,荷重 $P$ の各ピーク $p_{1}, p_{2}, p_{3}$ における変位 $\delta_{1}, \delta_{2}, \delta_{3}$ および荷重 $P_{1}, P_{2}, P_{3}$ を上層コアの高さ $h_{1}$ に対して关れ光れ示す . 図 7 中の実験式については次章にて詳述する . また , 図 8 中の $P_{1}, P_{2}, P_{3}$ に関する直線 は光れ光れの平均を表す。

Specimen

(1) (2) (3) (4) (5)

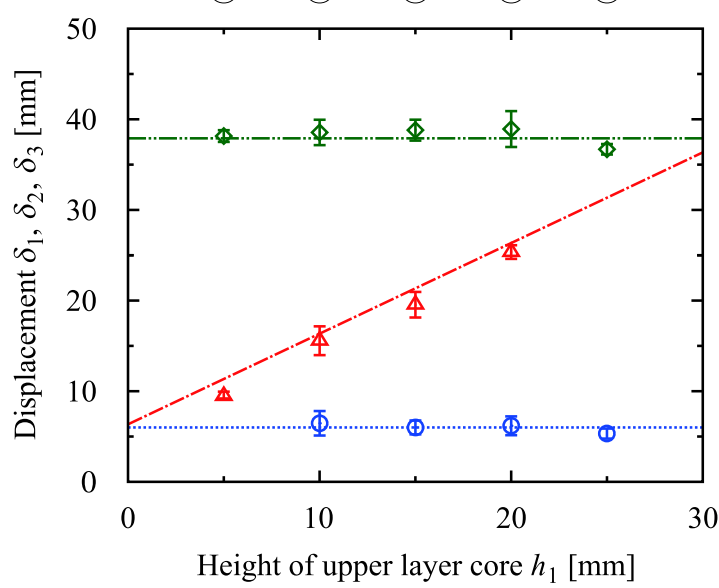

\begin{tabular}{|cccc|}
\hline$\circ$ & $\delta_{1}$ & $\ldots \ldots \ldots \ldots . .$. & Equation (16) \\
$\Delta$ & $\delta_{2}$ & -..-- Equation (17) \\
$\diamond$ & $\delta_{3}$ & -.... & Equation (18) \\
\hline
\end{tabular}

Fig. 7 The displacement at the peak loads
Specimen

(1) (2) (3) (4) (5)

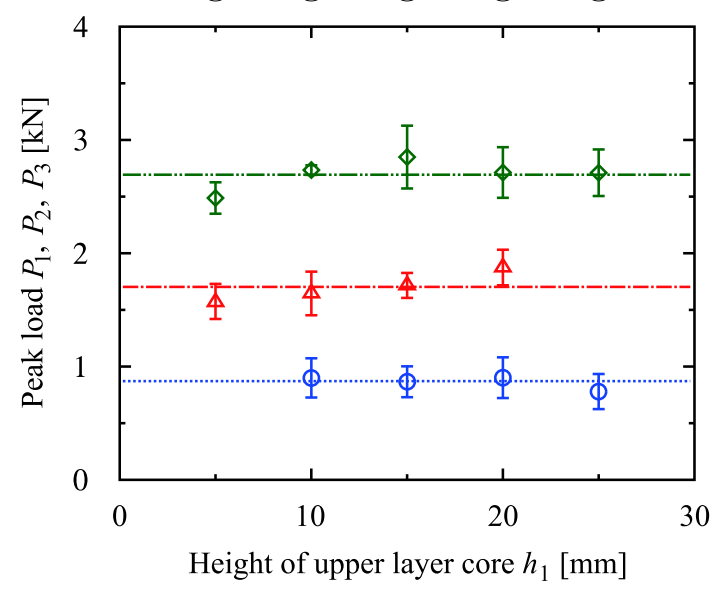

Fig. 8 The peak loads 
図 7 より, 変位 $\delta_{1}$ および変位 $\delta_{3}$ は上層コアの高さ $h_{1}$ によらず一定值をとり, 変位 $\delta_{2}$ は上層コアの高さ $h_{1}$ に 対して直線的に増加することが確認された . したがって , 変位 $\delta_{1}$ が一定值をとることから , 上層コアの高さ $h_{1}$ は 上板の変形に影響しないことが分かった . 変位 $\delta_{2}$ が上層コアの高さ $h_{1}$ に対して直線的に変化した理由は, 上層コ アの高さ $h_{1}$ が高くなるにつれて, コアが緻密化するまでに必要な変位が増加するためであると考えられる.変位 $\delta_{3}$ が一定值であった理由は, 各試験片のコアの総高さ $h$ が等しいためであると考えられる .

次に, ピークにおける荷重に注目すると，図 8 より，すべての試験片において， $P_{1}, P_{2}, P_{3}$ は光れ奖れ上層コア の高さ $h_{1}$ によらずほぼ一定值をとつた . これは，3·2·1で述べたようにコアによる押込みの抑制効果は小さく，各 平板による押込みの抑制効果が大きく影響していたことによる . また , これらの荷重は $P_{1}, P_{2}, P_{3}$ の順に大きくな

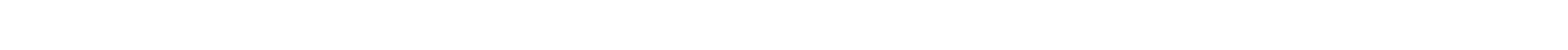
化させた後, 緻密化したコアと光の上に接着された平板すべてをさらに変形させるための力が必要であるためと 考えられる .

図 5 にみられたように , 各平板に生じたき裂はしぼり加工による引張応力の負荷によるものと考えられる . ま た，参考文献 (22) て既に報告しているように，荷重 $P_{1}, P_{2}, P_{3}$ には最高深しぼり応力が大きく影響する．弚こで， 最高深しぼり応力の式 ${ }^{(23)}$ を参考にして, 上板および下板のき裂発生点の破壊時の応力を以下のように求めた .

まず，上板におけるき裂発生点の破壞時の応力 $\sigma_{1}$ は次式で与えられる .

$$
\sigma_{1}=\frac{P_{1}}{2 \pi r_{1} t_{p}}
$$

ここで, $r_{1}$ は上板におけるき裂発生位置から凹みの中心までの最短距離である . 応力 $\sigma_{1}$ が平板の材質の引張強度 $\sigma_{B}$ に等しいとすると, 荷重 $P_{1}$ と距離 $r_{1}$ の関係式として

$$
P_{1}=2 \pi t_{p} \sigma_{B} \cdot r_{1}
$$

が得られる . 図 9 に本実験から得られた試験片(2)〜(5)の荷重 $P_{1}$ と距離 $r_{1}$ の関係を示す . 図中には平板の材質であ る A1100 材の引張強度を用いて， $\sigma_{B}=100 \mathrm{MPa}$ とした場合の式 (13)による理論直線も示す．図 9 より，実験結 果か理論値とよくあうことから，荷重 $P_{1}$ は上板にき裂が発生するときの荷重であることか確認された．また，荷 重 $P_{1}$ のばらつきはき裂発生点に依存していたと判断される .

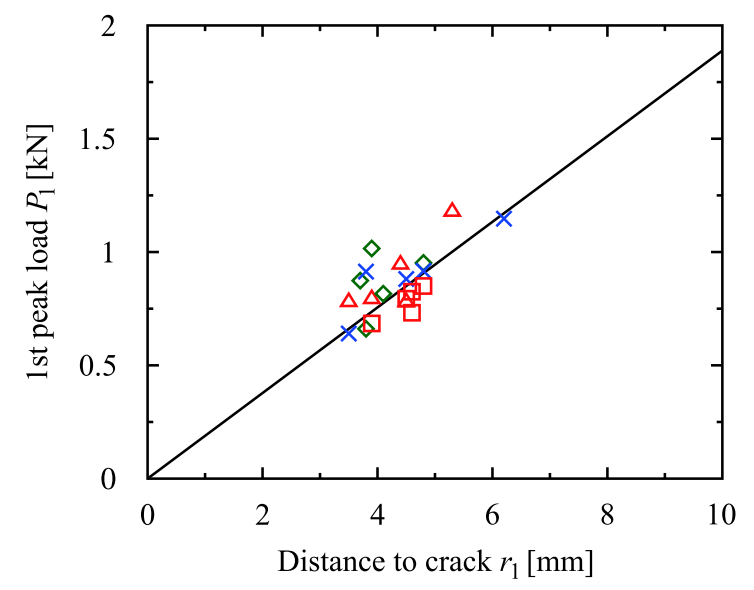

$\begin{array}{|ll|}\Delta & \text { (2) } h_{1}=10 \mathrm{~mm}, h_{2}=20 \mathrm{~mm} \\ \diamond & \text { (3) } h_{1}=15 \mathrm{~mm}, h_{2}=15 \mathrm{~mm} \\ \times & \text { (4) } h_{1}=20 \mathrm{~mm}, h_{2}=10 \mathrm{~mm} \\ \square & \text { (5) } h_{1}=25 \mathrm{~mm}, h_{2}=5 \mathrm{~mm} \\ & \text { Equation (13) }\end{array}$

Fig. 9 The relationships between the 1st peak load and the distance to crack on the top face sheet

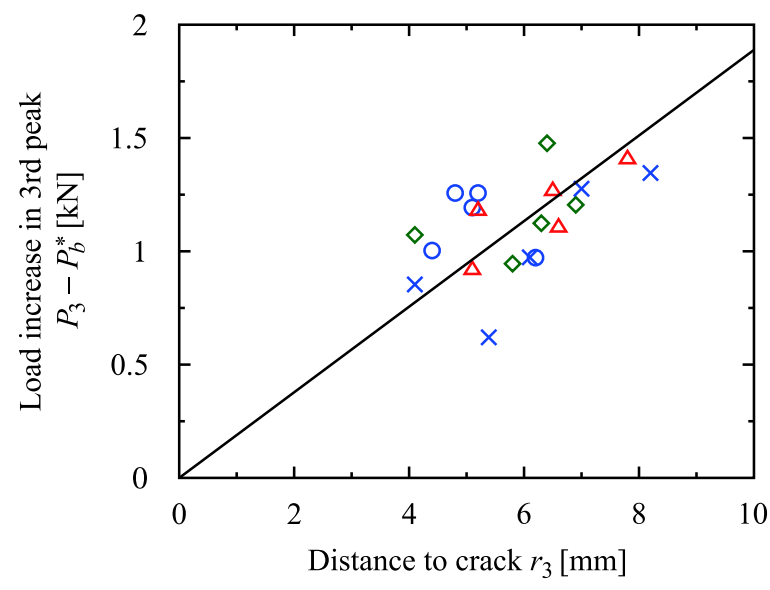

$\begin{aligned} \circ & \text { (1) } h_{1}=5 \mathrm{~mm}, h_{2}=25 \mathrm{~mm} \\ \Delta & \text { (2) } h_{1}=10 \mathrm{~mm}, h_{2}=20 \mathrm{~mm} \\ \diamond & \text { (3) } h_{1}=15 \mathrm{~mm}, h_{2}=15 \mathrm{~mm} \\ \times & \text { (4) } h_{1}=20 \mathrm{~mm}, h_{2}=10 \mathrm{~mm} \\ & \text { Equation (15) }\end{aligned}$

Fig. 10 The relationships between the 3rd peak load and the distance to crack on the bottom face sheet 
同樣にして ,ピーク $p_{3}$ において , 緻密化した上層コアと下層コア , ならびに光の上に接着された上板と中板を さらに変形させるための力の総和が , 3.2.3 にて詳述する二次荷重平衡領域の最低荷重 $P_{b}^{*}$ であるとして近似する と，下板におけるき裂発生点の破壞時の応力 $\sigma_{3}$ は次式で与えられる .

$$
\sigma_{3}=\frac{P_{3}-P_{b}^{*}}{2 \pi r_{3} t_{p}}
$$

ここで, $r_{3}$ は下板におけるき裂発生位置から凹みの中心までの最短距離である.式 (12) と同樣にして,$\sigma_{3}=\sigma_{B}$ と すると, 荷重 $P_{3}-P_{b}^{*}$ と距離 $r_{3}$ の関係式として

$$
P_{3}-P_{b}^{*}=2 \pi t_{p} \sigma_{B} \cdot r_{3}
$$

が得られる. 図 10 に本実験から得られた試験片(1)〜 (4)の荷重 $P_{3}-P_{b}^{*}$ と距離 $r_{3}$ の関係，および $\sigma_{B}=100 \mathrm{MPa}$ と した場合の式 (15) による理論直線を示す . 図 10 より，上板の場合と同樣にして，実験結果か理論值とよくあうこ とが分かる . 中板におけるき裂発生位置と凹みの中心までの最短距離の測定は困難であるため，中板におけるき 裂発生点の破壊時の応力は求められないが, 上板および下板と同樣の傾向があると考えられる .

\subsection{3 荷重平衡領域}

一次荷重平衡領域および二次荷重平衡領域における荷重 $P$ の平均值を光れ光れ $P_{a}, P_{b}$, 最低值を光れ光れ $P_{a}^{*}, P_{b}^{*}$ とおき，図 11 に， $P_{a}, P_{b}, P_{a}^{*}, P_{b}^{*}$ と光の平均を上層コアの高さ $h_{1}$ に対して光れ光れ示す. 前述したように，荷重 平衡領域はコアの圧潰に加え，錘による平板のさらなる押込み変形と発生したき裂の進展によって現れたと考え られ，荷重平衡領域における荷重 $P$ は，コアが緻密化するまでに必要な力と平板を押込む力の合力であると考え られる。

また，荷重 $P_{1}, P_{2}, P_{3}$ の場合と同樣に, 二次荷重平衡領域では下層コアが緻密化するまでに必要な力と中板を押 込む力に加え，緻密化した上層コアと上板をさらに変形させるための力が必要であるため, $P_{a}<P_{b}$ および $P_{a}^{*}<P_{b}^{*}$ となることが分かる .さらに, 荷重 $P_{a}, P_{b}, P_{a}^{*}, P_{b}^{*}$ も上層コアの高さ $h_{1}$ によらずほぼ一定値をとったことから , コ アによる押込みの抑制効果は小さく，各平板による押込みの抑制効果が大きく影響していたといえる .

図 11 において $, P_{b} \simeq 2 P_{a}, P_{b}^{*} \simeq 2 P_{a}^{*}$ となっている. これは, 二次荷重平衡領域において，緻密化した上層コ アと上板をさらに変形させるための力の和が , 下層コアが緻密化するまでに必要な力と中板を押込む力の和とほ

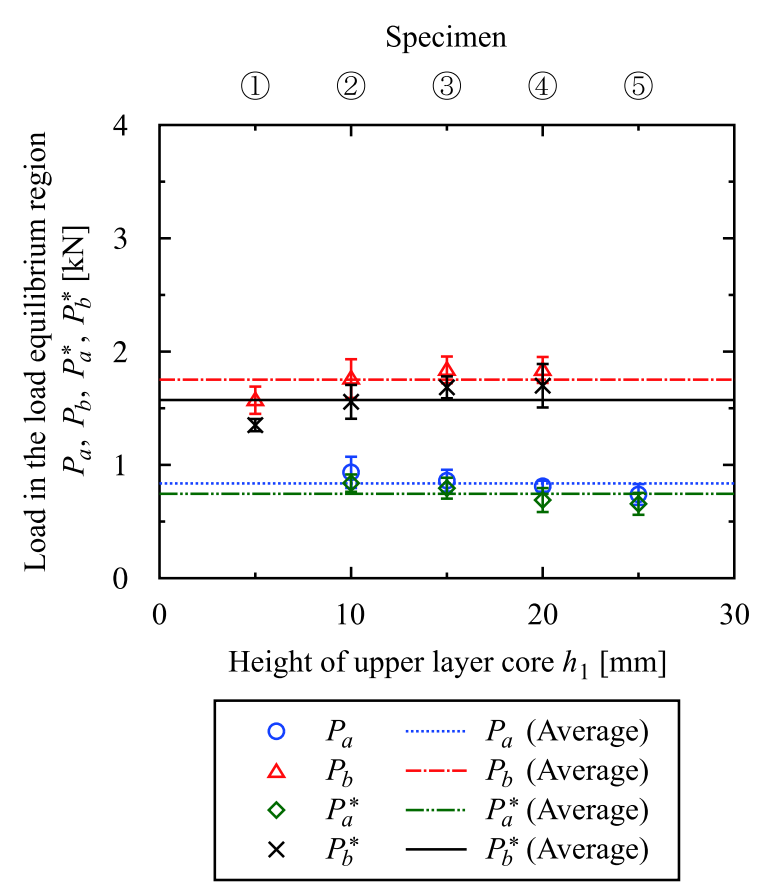

Fig. 11 The average and the minimum of the load in the load equilibrium region
Specimen

\begin{tabular}{|c|c|c|c|}
\hline o & $E_{1}$ & $\ldots \ldots \ldots \ldots$ & Equation (19) \\
\hline$\Delta$ & $E_{2}$ & $--\cdot--$ & Equation (20) \\
\hline$\nabla$ & $E_{1}+E_{2}$ & --- & Equation (21) \\
\hline$\diamond$ & $E_{3}$ & $-\cdots-\cdot \cdot$ & Equation (22) \\
\hline 口 & $E_{2}+E_{3}$ & $--\cdot-$ & Equation (23) \\
\hline$x$ & $E_{S}$ & $\longrightarrow$ & Equation (24) \\
\hline
\end{tabular}

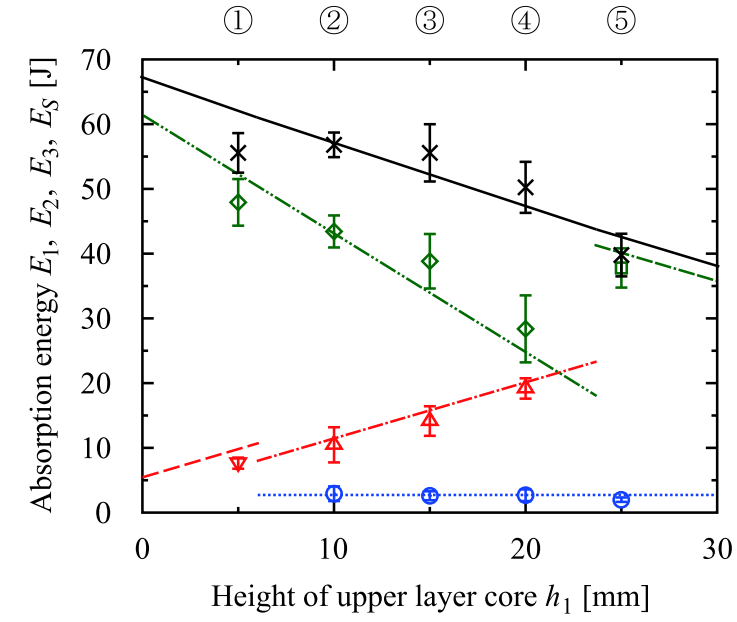

Fig. 12 The absorption energies 
ぼ同程度であったためと考えられる．なお，錘の寸法が小さく，錘が上板を貫通した後に中板に到達する場合など では, 二次荷重平衡領域において, 上板をさらに変形させるための力が大幅に減少し, $P_{a}$ と $P_{b}, P_{a}^{*}$ と $P_{b}^{*}$ の光れ

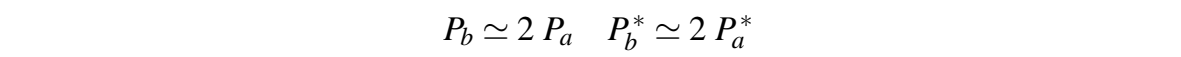

\section{$3 \cdot 3$ エネルギー吸収量}

図 12 に，エネルギ一吸収量 $E_{1}, E_{2}, E_{3}, E_{S}$ を上層コアの高さ $h_{1}$ に対して光れ光れ示す . 図中の実験式について は次章にて詳述する．なお，試験片(1)ではピーク $p_{1}$ か現れないことから， $E_{1}$ と $E_{2}$ を分離できないため，図中に は $E_{1}+E_{2}$ の值を示す . 同樣にして , 試験片(5)ではピーク $p_{2}$ か現れないため , 図中には $E_{2}+E_{3}$ の值を示す . 図 12 より, $E_{1}, E_{2}, E_{3}$ の総和であるエネルギー吸収限界量 $E_{S}$ は上層コアの高さ $h_{1}$ に対して，ほぼ直線的に減少し た .この理由について，エネルギー吸収量 $E_{1}, E_{2}, E_{3}$ を用いて説明する .

まず， $E_{1}$ は上層コアの高さ $h_{1}$ によらず一定值をとった .これは図 7 および図 8 より，ピーク $p_{1}$ における変位 $\delta_{1}$ および荷重 $P_{1}$ が上層コアの高さ $h_{1}$ によらず一定であったためである . 次に，上層コアの高さ $h_{1}$ に対して， $E_{2}$ は直線的に増加し， $E_{3}$ は直線的に減少した .これは，図 8 および図 11 より，ピーク $p_{1} \sim p_{2}$ 間の荷重 $\left(P_{1}, P_{2}, P_{a}\right.$ ， $\left.P_{a}^{*}\right)$ とピーク $p_{2} \sim p_{3}$ 間の荷重 $\left(P_{2}, P_{3}, P_{b}, P_{b}^{*}\right)$ が上層コアの高さ $h_{1}$ によらず一定値をとった一方で，図 7 より， 上層コアの高さ $h_{1}$ が高くなるにつれてピーク $p_{1} \sim p_{2}$ 間の変位量 $\delta_{2}-\delta_{1}$ が直線的に増加し，ピーク $p_{2} \sim p_{3}$ 間の 変位量 $\delta_{3}-\delta_{2}$ が直線的に減少したためである.

また，上層コアの高さ $h_{1}$ に対する傾きの絶対值は $E_{2}$ よりも $E_{3}$ の方が大きくなった . これは図 8 および図 11 より，ピーク $p_{2} \sim p_{3}$ 間の方がピーク $p_{1} \sim p_{2}$ 間よりも大きい荷重て推移したためである . 以上より，エネルギー 吸収限界量 $E_{S}$ は, 上層コアの高さ $h_{1}$ に対して，ほぼ直線的に減少したのである .

\section{4. 設 計 指 針}

本実験結果より，二層積層 HSP の荷重一変位線図について，上層コアの高さ $h_{1}$ が高いほど , 荷重 $P$ の度目の ピーク (試験片(1)では一度目のピーク) $p_{2}$ の発生する変位 $\delta_{2}$ が大きくなることが分かった . エネルギー吸収量に ついては, 上層コアの高さ $h_{1}$ が高いほど，エネルギー吸収限界量 $E_{S}$ は小さくなることが分かった .一方で，上 層コアの高さ $h_{1}$ が高いほど，ピーク $p_{2}$ 到達前の比較的小さい荷重で吸収できるエネルギー量 $E_{2}$ は大きくなり， より大きい荷重で吸収するエネルギー量 $E_{3}$ は小さくなることが分かった .

前章で述べたように，二層積層 HSP においてコアによる押込みの抑制効果が小さく，各平板による押込みの抑 制効果が大きい場合, 荷重に関するパラメータ (変形抵抗 $K_{1}, K_{2}, K_{3}$, ピークにおける荷重 $P_{1}, P_{2}, P_{3}$, 荷重平衡領 域における荷重の平均値 $P_{a}, P_{b}$ および最小值 $\left.P_{a}^{*}, P_{b}^{*}\right)$ は上層コアの高さ $h_{1}$ に関係なくほぼ一定値をとった .さら に，変形抵抗 $K_{1}, K_{2}, K_{3}$ についてはすべてほぼ等しい値をとった . 弚こで, 本研究では設計指針として, 二層積 層 HSP の荷重一変位線図を直線で近似したエネルギー吸収モデルを作成し, 荷重に関するパラメータから, 積層 コアの高さの比率 , すなわちコアの総高さ $h$ を一定として上層コアの高さ $h_{1}$ の值を変えた場合における荷重の各 ピーク $p_{1}, p_{2}, p_{3}$ の生じる变位 $\delta_{1}, \delta_{2}, \delta_{3}$ ，およびエネルギ一吸収量 $E_{1}, E_{2}, E_{3}, E_{S}$ を見積もる方法を提案する .

$4 \cdot 1$ エネルギー吸収モデルによる荷重のピークが生じる変位とエネルギー吸収量の見積方法

図 13 に作成したエネルギー吸収モデルを示す. 本エネルギ一吸収モデルにおいて, 荷重 $P_{1}, P_{2}, P_{3}, P_{a}, P_{b}, P_{a}^{*}, P_{b}^{*}$ はすべて上層コアの高さ $h_{1}$ に依存しないとする . また , すべての荷重上昇領域で変位 $\delta$ に対する荷重 $P$ の傾き を $K_{c}$ として直線近似し，一次荷重平衡領域および二次荷重平衡領域における荷重を光れ光れ $P_{a}, P_{b}$ で一定とする. ここで, 一次荷重平衡領域から二次荷重上昇領域に移行するときの荷重を $P_{a}^{*}$, 変位を上層コアの高さ $h_{1}$ と等しい として近似する．同樣にして，二次荷重平衡領域から三次荷重上昇領域に移行するときの荷重を $P_{b}^{*}$, 変位をコア の総高さ $h$ と等しいとして近似する.

なお，試験片(1)にみられたように $h_{1}<\delta_{1}$ となる場合には，原点〜 $p_{1}$ 間を図 13 右の実線で示すように折れ線近 似する．これは試験片(5)にみられたように， $h<\delta_{2}$ となる場合についても同樣である．ここで, 変位 $\delta_{1}$ および $\delta_{2}$ の值は後述の式 (16) および式 (17) によって求める.

本エネルギー吸収モデルを用いて, コアの総高さ $h$ を一定として上層コアの高さ $h_{1}$ の值を変えた場合の変位 $\delta_{1}$, $\delta_{2}, \delta_{3}$, およびエネルギー吸収量 $E_{1}, E_{2}, E_{3}, E_{S}$ を以下のようにして見積もる. 

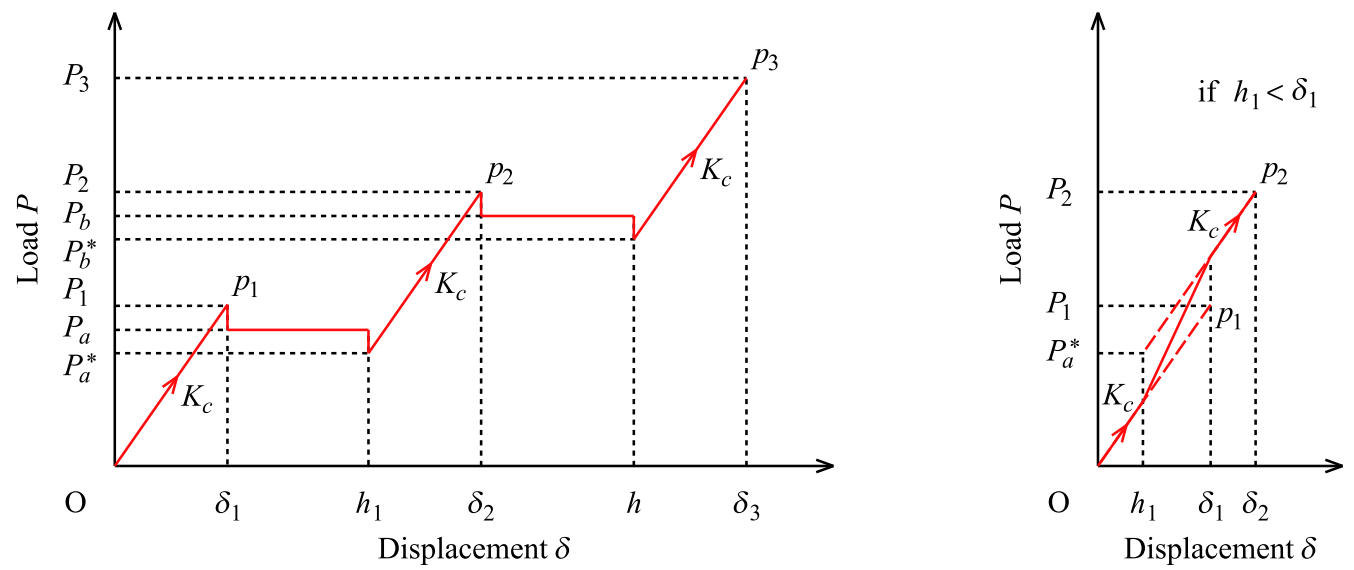

Fig. 13 The energy absorption model

（1）荷重のピークが三度現れる，適当な積層コアの高さの比率を持たせた二層積層 HSP (コアの総高さ $h$ ) から 荷重に関する各パラメータ $\left(K_{c}, P_{1}, P_{2}, P_{3}, P_{a}, P_{b}, P_{a}^{*}, P_{b}^{*}\right)$ を取得する.ここで， $K_{c}$ には変形抵抗 $K_{1}, K_{2}, K_{3}$ の平均値を用いる .

(2) 荷重の各ピーク $p_{1}, p_{2}, p_{3}$ の生じる変位 $\delta_{1}, \delta_{2}, \delta_{3}$ を次式より求める.

$$
\begin{aligned}
& \delta_{1}=\frac{P_{1}}{K_{c}} \\
& \delta_{2}=h_{1}+\frac{P_{2}-P_{a}^{*}}{K_{c}} \\
& \delta_{3}=h+\frac{P_{3}-P_{b} *}{K_{c}}
\end{aligned}
$$

(3) 各エネルギー吸収量 $E_{1}, E_{2}, E_{3}, E_{S}$ を次式より求める.

$$
\begin{aligned}
E_{1} & =\frac{P_{1}^{2}}{2 K_{c}} & & \left(\frac{P_{1}}{K_{c}} \leq h_{1} \leq h\right) \\
E_{2} & =P_{a}\left(h_{1}-\frac{P_{1}}{K_{c}}\right)+\frac{P_{2}^{2}-P_{a}^{* 2}}{2 K_{c}} & & \left(\frac{P_{1}}{K_{c}} \leq h_{1} \leq h-\frac{P_{2}-P_{a}^{*}}{K_{c}}\right) \\
E_{1}+E_{2} & =\frac{\left(P_{1}+P_{a}^{*}\right)\left(K_{c} h_{1}-P_{a}^{*}\right)+P_{2}^{2}}{2 K_{c}} & & \left(0 \leq h_{1}<\frac{P_{1}}{K_{c}}\right) \\
E_{3} & =P_{b}\left(h-h_{1}-\frac{P_{2}-P_{a}^{*}}{K_{c}}\right)+\frac{P_{3}^{2}-P_{b}^{* 2}}{2 K_{c}} & & \left(0 \leq h_{1} \leq h-\frac{P_{2}-P_{a}^{*}}{K_{c}}\right) \\
E_{2}+E_{3} & =P_{a}\left(h_{1}-\frac{P_{1}}{K_{c}}\right)+\frac{\left(P_{2}+P_{b}^{*}\right)\left\{K_{c}\left(h-h_{1}\right)-\left(P_{b}^{*}-P_{a}^{*}\right)\right\}+P_{3}^{2}-P_{a}^{* 2}}{2 K_{c}} & & \left(h-\frac{P_{2}-P_{a}^{*}}{K_{c}}<h_{1} \leq h\right) \\
E_{S} & =E_{1}+E_{2}+E_{3} & &
\end{aligned}
$$

\section{$4 \cdot 2$ 本見積方法の検証}

本方法の有効性について検証するため，例として，試験片(3)の実験值を用い，上層コアの高さ $h_{1}$ に対する変位 $\delta_{1}, \delta_{2}, \delta_{3}$ とエネルギー吸収量 $E_{1}, E_{2}, E_{3}, E_{S}$ の変化を見積もった . 試験片(3)の実験値を表 5 に示す . 表 5 の值を用 いて，式(16)〜式(18)によって得られた計算値は図 7 に示したとおりである．また，式 (19)〜式 (24) による計算 值は図 12 に示したとおりである . 図 7 および図 12 より，実験值と計算值がよく合うことか確認された .さらに， 図中の試験片(3) $\left(h_{1}=15 \mathrm{~mm}\right)$ における実験値と計算值の間の誤差はモデル化による誤差であるといえる .

表 5 に示した各パラメータは, 積層コアの高さの比率の異なる試験片(2), (4)であってもほぼ等しい值であるため, 試験片(3)の代わりに試験片(2)あるいは試験片(4)の実験值を用いても，図 7 おひび図 12 に示したものとほぼ同樣の 計算值が得られる．したがって，荷重のピークが三度現れる，適当な積層コアの高さの比率を持たせた二層積層 
Table 5 The experimental values of Specimen (3)

\begin{tabular}{c|c|c|c|c|c|c|c|c}
\hline \hline$h[\mathrm{~mm}]$ & $K_{c}[\mathrm{kN} / \mathrm{m}]$ & $P_{1}[\mathrm{kN}]$ & $P_{2}[\mathrm{kN}]$ & $P_{3}[\mathrm{kN}]$ & $P_{a}[\mathrm{kN}]$ & $P_{b}[\mathrm{kN}]$ & $P_{a}^{*}[\mathrm{kN}]$ & $P_{b}^{*}[\mathrm{kN}]$ \\
\hline 30 & 147 & 0.87 & 1.72 & 2.85 & 0.86 & 1.83 & 0.79 & 1.68 \\
\hline
\end{tabular}

HSP から表 5 に示した各パラメータを取得し，式 (16)〜(24) を用いることで, 積層コアの高さの比率を変えた場 合における荷重の各ピークの生じる変位, およびエネルギー吸収量を見積もることができることが確認された .

\section{5. 結言}

コアの総高さを $30 \mathrm{~mm}$ 一定として , 積層コアの高さの比率を変化させた二層積層ハニカムサンドイッチパネル を用いて落錘衝撃試験を行い, 以下の結論が得られた .

（1）荷重一変位線図において, 上層コアの高さが $5 \mathrm{~mm}$ および $25 \mathrm{~mm}$ の試験片からは荷重のピークが二度, 上層 コアの高さが $10 〜 20 \mathrm{~mm}$ の試験片からは荷重のピークが三度確認された .

（2）荷重の最後のピークに至るまでの荷重一変位線図には，荷重上昇領域と荷重平衡領域が存在した。

(3) 荷重上昇領域における変形抵抗, ならびに荷重平衡領域における荷重変動に及ぼすコア高さの影響はみられ なかった .

（4）ピークにおける荷重は平板と緻密化したコアの影響を受けて発生した順に大きくなったが，コア高さの影響 はみられなかった .

（5）上層コアの高さが低いほど，エネルギー吸収限界量は大きくなった．一方，上層コアの高さが高いほど，荷 重の大きい二度目の荷重のピークが現れる変位が大きくなるため, 小さい荷重で吸収できるエネルギー量が 大きくなった .

（6）本実験結果から，二層積層 HSP のエネルギー吸収モデルを作成した . 作成したエネルギー吸収モデルを用い て , 二層積層 HSP の基礎的実験データから，積層コアの高さの比率を変えた場合における荷重の各ピークの 生じる変位, およびエネルギー吸収量を見積もることができることを確認した．

$$
\text { 文献 }
$$

(1) 宮入裕夫, サンドイッチ構造の基礎 (1999), pp. 17-28, 日刊工業新聞社.

(2) 先端材料技術協会 (監修), 佐藤孝 (編集), ハニカム構造材料の応用 (2002), シーエムシー.

(3) 先端材料技術協会 (監修), 野口元 (編集), ハニカム構造の応用と機能一ハニカム構造材料からナノハニカム構造までー (2008), シーエムシー.

（4）武市通文, 奥野澄生, 岡崎正人, 鶴田仁,“高速鉄道車両用アルミニウム合金製車体構造の強度特性 (第 1 報, ろう付八二カ ムサンドイッチパネルの静的強度特性と車体構造の強度信頼性評価) ”, 日本機械学会論文集 A 編, Vol. 68, No. 666 (2002), pp. 319-326.

(5) 武市通文, 奥野澄生, 岡崎正人, 鶴田仁,“高速鉄道車両用アルミニウム合金製車体構造の強度特性 (第 2 報, 万う付八二カ ムサンドイッチパネルの疲労強度特性と車体構造の強度信頼性評価) ”, 日本機械学会論文集 A 編, Vol. 68, No. 666 (2002), pp. 327-334.

（6）武市通文, 奥野澄生, 鶴田仁, 岡崎正人, 廣瀬進,“高速鉄道車両用アルミニウム合金製車体構造の強度特性 (第 3 報, 実物 大車体の圧力疲労試験による強度信頼性評価)”, 日本機械学会論文集 A 編, Vol. 68, No. 666 (2002), pp. 335-342.

(7) 康井義明, 粕谷平和, 森山裕幸, 國本隆, 馬場武明, 奥戶行一郎,“衝撃荷重を受ける多段積層ハニカムパネルの緩衝特性”, 日本機械学会論文集 A 編, Vol. 61, No. 589 (1995), pp. 1979-1985.

（8）小笠原永久, 白鳥正樹, 宮原進, 干強,“ 八ニカム構造材料の衝撃吸収特性に関する研究（第 1 報, 準静的状態における逐次 座屈現象) ”, 日本機械学会論文集 A 編, Vol. 63, No. 608 (1997), pp. 774-779.

(9) 小笠原永久, 白鳥正樹, 宮原進, 干強, 宮野篤,“ 八ニカム構造材料の衝撃吸収特性に関する研究 (第 2 報, 衝撃圧潰応力の 評価) ”, 日本機械学会論文集 A 編, Vol. 63, No. 616 (1997), pp. 2575-2579. 
(10) Fleck, N.A. and Deshpande, V.S., "The Resistance of Clamped Sandwich Beams to Shock Loading", Transactions of the ASME, Journal of Applied Mechanics, Vol. 71, No. 3 (2004), pp. 386-401.

(11) 小笠原永久, 千葉矩正, 別府万寿博, 河島庸一, 小林英治, 菊地祐仁, “減肉ハ二カム材料の衝撃圧潰荷重式の提案”, 日本機 械学会論文集 A 編, Vol. 74, No. 746 (2008), pp. 1314-1320.

(12) Ogasawara, N., Chiba, N., Kobayashi, E. and Kikuchi, Y., "Crushing Strength of Aluminum Honeycomb with Thinning Cell Wall”, Journal of Solid Mechanics and Materials Engineering, Vol. 4, No. 8 (2010), pp. 1338-1345.

(13) Miller, W., Smith, C.W. and Evans, K.E., "Honeycomb Cores with Enhanced Buckling Strength”, Composite Structures, Vol. 93 , No. 3 (2011), pp. 1072-1077.

(14) 渡邊正憲, 大塚年久, 田村宏, 小林志好,“ ハニカムサンドイッチパネルの衝撃特性に関する研究”, 日本機械学会論文集 A 編, Vol. 69, No. 678 (2003), pp. 257-264.

(15) 野村聡一, 大塚年久, 田村宏, 小林志好,“ ハニカムサンドイッチ曲面板の曲げ特性に関する研究”, 日本機械学会論文集 A 編, Vol. 69, No. 679 (2003), pp. 671-677.

(16) Rathbun, H.J., Radford, D.D., Xue, Z., He, M.Y., Yang, J., Deshpande, V., Fleck, N.A., Hutchinson, J.W., Zok, F.W. and Evans, A.G., "Performance of Metallic Honeycomb-core Sandwich Beams under Shock Loading", International Journal of Solids and Structures, Vol. 43, No. 6 (2006), pp. 1746-1763.

(17) 小林志好, 大塚年久, 辻田勝人, 安部勇仁, 岸本喜直,“周辺固定されたハニカムコアサンドイッチパネルの局部圧縮疲労”， 日本機械学会論文集 A 編, Vol. 77, No. 775 (2011), pp. 415-426.

(18) 小林志好, 大塚年久, 田村宏, 佐藤岳大, 中島裕之,“ 二層積層アルミハニカムサンドイッチパネルの曲げ特性に関する研究”, 日本機械学会論文集 A 編, Vol. 72 , No. 724 (2006), pp. 2050-2057.

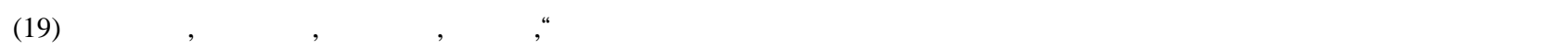
れの高さの影響”, 日本機械学会論文集 A 編, Vol. 73, No. 727 (2007), pp. 440-446.

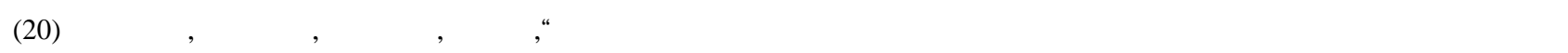
れのセル壁厚さの影響”, 日本機械学会論文集 A 編, Vol. 73, No. 730 (2007), pp. 744-750.

(21) 辻田勝人, 小林志好, 大塚年久,“周辺固定された二層積層ハニカムコアサンドイッチパネルの局部圧縮疲労”, 日本機械学 会論文集 A 編, Vol. 75, No. 758 (2009), pp. 1416-1423.

（22）小林志好, 大塚年久, 平原誠也,“ 二層積層ハニカムコアサンドイッチパネルの落鍾衝撃特性”, 日本機械学会論文集 A 編, Vol. 75, No. 758 (2009), pp. 1409-1415.

(23) 福井伸二, 竹山寿夫, 吉田清太, 阿部邦雄,“深絞り加工の限界”, 日本機械学会誌, Vol. 55, No. 405 (1952), pp. 640-646. 